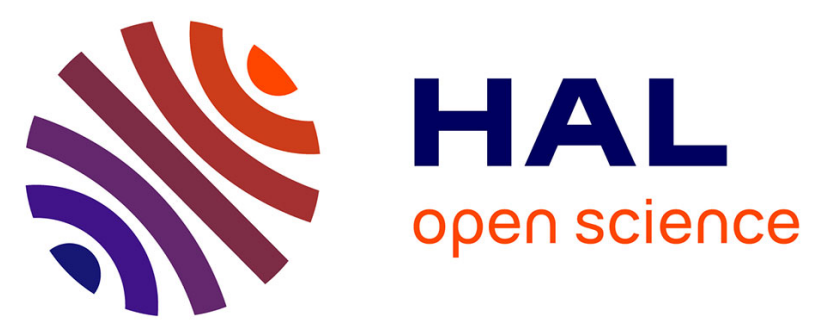

\title{
Synthesis, X-ray crystal structures, electrochemistry and theoretical investigation of a tetradentate nickel and copper Schiff base complexes
}

Samra Rahmouni, Amel Djedouani, Barkahem Anak, Salima Tabti, Abderrahmen Bendaas, Mustapha Bencharif, Michel Francois, Solenne Fleutot, Franck Rabilloud

\section{To cite this version:}

Samra Rahmouni, Amel Djedouani, Barkahem Anak, Salima Tabti, Abderrahmen Bendaas, et al.. Synthesis, X-ray crystal structures, electrochemistry and theoretical investigation of a tetradentate nickel and copper Schiff base complexes. Journal of Molecular Structure, 2017, 1148, pp.238-246. 10.1016/j.molstruc.2017.07.032 . hal-02317599

\section{HAL Id: hal-02317599 \\ https://univ-lyon1.hal.science/hal-02317599}

Submitted on 18 Jan 2020

HAL is a multi-disciplinary open access archive for the deposit and dissemination of scientific research documents, whether they are published or not. The documents may come from teaching and research institutions in France or abroad, or from public or private research centers.
L'archive ouverte pluridisciplinaire HAL, est destinée au dépôt et à la diffusion de documents scientifiques de niveau recherche, publiés ou non, émanant des établissements d'enseignement et de recherche français ou étrangers, des laboratoires publics ou privés. 


\title{
Synthesis, X-ray crystal structures, electrochemistry and theoretical investigation of a tetradentate nickel and copper Schiff base complexes
}

\author{
Samra Rahmouni ${ }^{\mathrm{a}}$, Amel Djedouani ${ }^{\mathrm{b}, \mathrm{c}}$, Barkahem Anak ${ }^{\mathrm{c}, \mathrm{d}}$, Salima Tabti ${ }^{\mathrm{e}}$, Abderrahmen \\ Bendaas $^{\mathrm{a}}$, Mustapha Bencharif ${ }^{\mathrm{c}, \mathrm{d}}$, Michel François ${ }^{\mathrm{f}}$, Solenne Fleutot ${ }^{\mathrm{e}}$, Franck Rabilloud ${ }^{\mathrm{q}}$
}

a'Laboratoire d'Electrochimie des Matériaux Moléculaires et Complexes (LEMMC). Département de Génie des procédés, Faculté de Technologie, Université Ferhat Abbas Sétif-1, Algérie.

${ }^{\mathbf{b}}$ Laboratoire de Physicochimie Analytique et Cristallochimie des Matériaux Organométalliques et Biomoléculaires, Constantine1.

${ }^{c}$ Ecole normale supérieure de Constantine. Ville Universitaire Ali Mendjli Constantine 3, Algérie ${ }^{\mathrm{d}}$ Laboratoire de chimie des matériaux de Constantine. Faculté des Sciences Exactes, Université des frères Mentouri-Constantine 25000, Algérie

${ }^{\text {e}}$ Faculté des sciences et technologie, département SM, Université de Mohamed el Bachir el Ibrahimi, El Anasser- Bordj Bou-Arréridj 34000, Algérie.

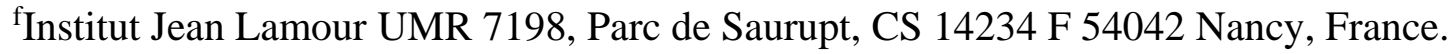

gUniv Lyon, Université Claude Bernard Lyon 1, CNRS, Institut Lumière Matière, F-69622, Villeurbanne, France

*Corresponding author: Franck Rabilloud, franck.rabilloud@univ-lyon1.fr

\begin{abstract}
New tetradentate mononuclear nickel(II) [NiL] and pentadentate binuclear copper(II) $\left[\mathbf{C u}_{2} \mathbf{L}_{2} \mathbf{H}_{2} \mathbf{O}\right.$ ], $\mathbf{H}_{2} \mathbf{O}$ Schiff base complexes have been synthesized. The crystal structures of [NiL] and $\left[\mathrm{Cu}_{2} \mathrm{~L}_{2} \mathrm{H}_{2} \mathrm{O}\right], \mathrm{H}_{2} \mathrm{O}$ have been determined by X-ray diffraction method showing distorted squareplanar geometry for [NiL] and distorted tetragonal pyramid geometry for $\left[\mathrm{Cu}_{2} \mathbf{L}_{2} \mathbf{H}_{2} \mathrm{O}\right], \mathbf{H}_{2} \mathrm{O}$. In both complexes, the dehydroacetic acid functional group engages in a deprotonated manner and coordination occurs through the nitrogen atoms of the imine function and the phenolic oxygen. Density Functional Theory calculations are carried out for the determination of the optimized structures. The fundamental vibrational wave numbers are calculated and a good agreement between observed and calculated wave numbers is achieved.
\end{abstract}


Keywords: Metal complexes, Crystallography Electrochemistry, Quantum chemical Calculations (DFT).

\section{Introduction}

Schiff base ligands that containing oxygen and nitrogen donors set represent one of the most widely utilized classes of ligands and have been of research interest in different aspects in recent decades, because of the versatility of their steric and electronic properties, which can be modified by choosing the appropriate amine precursors and ring substituents. Metal complexes with Schiff bases as ligands have played a considerable attention in the development of coordination chemistry because they have high stability and important properties in different oxidation states [1-4]. Some complexes with tetradentate $\mathrm{N}_{2} \mathrm{O}_{2}$ donor Schiff base ligands have been extensively studied in the past years $[\mathbf{5 , 6 ]}$. Therefore, Schiff base ligands derived from dehydroacetic acid (dha= 3-acetyl-4hydroxy-6-methyl-2H-pyrone-2-one) are widely used to coordinate various metal ions because of the high stability of their complexes [5-8]. Furthermore, studies have shown that such compounds and their complexes have very interesting biological activity such as antimicrobial, antifungal, antitumor and herbicides [9-17], pharmacological [1819] and medicinal properties [20, 21].

In this work, synthesis of [NiL] and $\left[\mathrm{Cu}_{2} \mathbf{L}_{2} \mathbf{H}_{2} \mathbf{O}\right], \mathbf{H}_{2} \mathbf{O}$ complexes is reported using (N,N'bis(dehydroaceto)ethylenediimine) as Ligand (L) (Scheme 1). Single crystal X-Ray Diffraction and quantum chemical calculations are used in order to confirm the structure of complexes. The spectral study using FT-IR, and UV-visible analyses are also investigate in order to find a correlation between molecular structure and vibrational frequencies of complexes. Electrochemical investigation of complexes is also performed. 


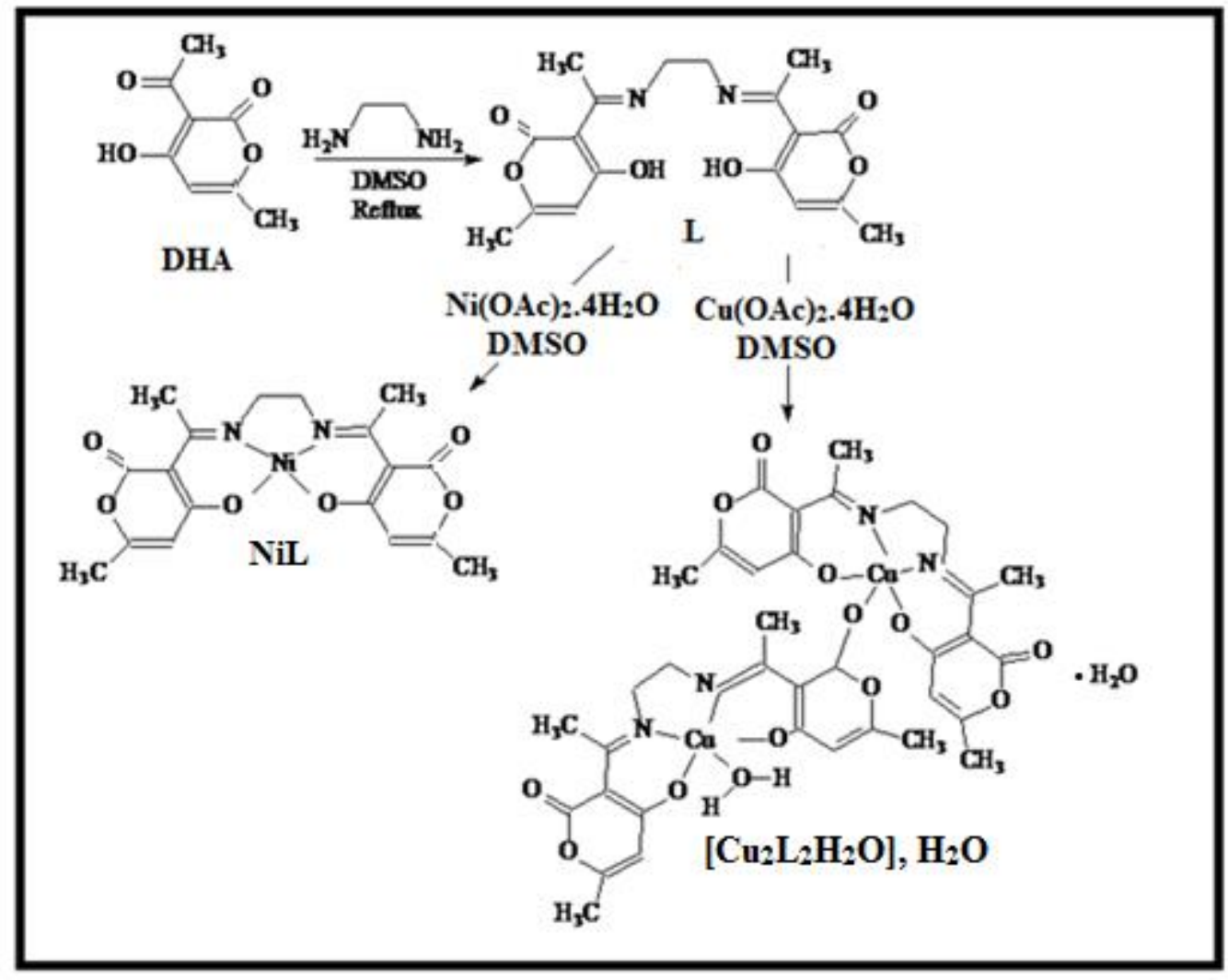

Scheme.1. Reaction way leading to the formation of the nickel and copper Schiff base complexes.

\section{Experimental}

\subsection{Reactants}

All reactants and solvents were analytical grade and used without further purification. Ethylendiamine and dehydroacetic acid was purchased from Sigma-Aldrich. Nickel and copper hydrated acetate (Prolabo) were used as received.

\subsection{Measurements}

The IR spectra were obtained on a Shimadzu FTIR-Affinity-1 spectrometer with KBr pellets in the 4000-400 $\mathrm{cm}^{-1}$ region. The electronic absorption spectra were carried out on a Shimadzu UV1800 spectrophotometer using DMSO as solvent. The melting point complexes were determined with a Kofler Banc 7779 apparatus. Cyclic voltammetry was performed with a VoltaMaster 4 software under a nitrogen atmosphere in a one-compartment electrolysis cell consisting of a glassy carbon working electrode (GC), a platinum wire counter electrode and all potentials are expressed versus the saturated solution of calomel electrode (SCE). Cyclic voltammograms were monitored at scan rates of $400,300,200,100,75,50,25$ and $10 \mathrm{mV} \mathrm{s}^{-1}$ and recorded in DMSO. The 
concentrations of the complexes were maintained at $10^{-3} \mathrm{M}$, and each solution contained $0.1 \mathrm{M}$ tetrabutylammonium perchlorate $\left(\mathrm{TBAPF}_{4}\right)$ as the electrolyte.

\subsection{Crystal data collection and processing}

X-ray single-crystal diffraction data were collected at $293 \mathrm{~K}$ on a Diffractomer BrukerNonius and goniometre Kappa CCD, equipped with a graphite monochromator using Mo/Ka radiation $(\lambda=0.71073 \AA)$. Cell refinement and data reduction were carried out with the APEX2 Software [22]. Structures were solved by direct methods and refined on $\mathrm{F}^{2}$ by full-matrix leastsquares method, using SHELX97 package [23]. All non-H atoms were refined anisotropically by the full matrix least squares method on $\mathrm{F}^{2}$ using SHELXL [24] and the $\mathrm{H}$ atoms were included at the calculated positions and constrained to ride on their parent atoms.

\subsection{Computational studies}

The geometry of complexes, in the gas phase, have been fully optimized within the density functional theory method (DFT) using the GAUSSIAN 09 program package [25], as DFT methods[26] are very effective in modeling compounds and have good experimental correlations with the IR frequencies. DFT calculations were performed using the hybrid Becke's three parameter and the Lee-Yang-Parr functional (B3LYP) [27-28], one of the most popular density functional method, and using 6-311G(d,p) and LANL2DZ basis sets.

\subsection{Synthesis and characterization}

\subsubsection{Synthesis of the ligand $(L)$}

The (N,N'-bis(dehydroaceto)ethylenediimine) ligand was prepared by the reaction of one mole of ethylendiamine with two mole of dehydroacetic acid in absolute $\mathrm{EtOH}$ according to the literature [29].

\subsubsection{Synthesis of [NiL]}

$\mathrm{Ni}(\mathrm{OAc}) 2.4 \mathrm{H}_{2} \mathrm{O}(0.062 \mathrm{~g}, 0.25 \mathrm{mmol}, 10 \mathrm{~mL}$ DMSO) was slowly added to the ligand $(0.080$ g, $0.25 \mathrm{mmol}, 10 \mathrm{~mL}$ DMSO), under nitrogen atmosphere and refluxing conditions. The reflux was maintained for $25 \mathrm{~h}$. By slow evaporation of the orange solution, single orange crystals of [NiL] were removed by filtration and then dried in vacuum. Yield: $65 \%$; $\mathrm{mp}=293^{\circ} \mathrm{C}$; FT-IR $(\mathrm{KBr}$ pellets, $\left.v \mathrm{~cm}^{-1}\right): 3435(\mathrm{O}-\mathrm{H}) ; 1560(\mathrm{C}=\mathrm{N}) ; 1180(\mathrm{C}-\mathrm{O}), 1643(\mathrm{C}=\mathrm{O})$; UV/Vis: DMSO, $\lambda(\mathrm{nm})$ 281, 310, 370, 575. 


\subsubsection{Synthesis of $\left[\mathrm{Cu}_{2} \mathrm{~L}_{2} \mathrm{H}_{2} \mathrm{O}\right], \mathrm{H}_{2} \mathrm{O}$}

To a solution of ligand $\left(0.25 \mathrm{mmol}, 0.08 \mathrm{~g}\right.$, DMSO) was added $\mathrm{Cu}(\mathrm{OAc}) 2.4 \mathrm{H}_{2} \mathrm{O}(0.062 \mathrm{~g}$, $0.25 \mathrm{mmol}, 10 \mathrm{~mL}$ DMSO) with a 1: 2 stiochiometric, under nitrogen atmosphere and refluxing conditions and kept at an appropriate temperature and then allowed to stand for two days. Single blue crystals of complex $\left[\mathrm{Cu}_{2} \mathrm{~L}_{2} \mathrm{H}_{2} \mathrm{O}\right], \mathrm{H}_{2} \mathrm{O}$ were removed by filtration and then dried in vacuum. Yild : $75 \%$; $\mathrm{mp}=293^{\circ} \mathrm{C}$; IR $\left(\mathrm{KBr}\right.$ pellets, $\left.v \mathrm{~cm}^{-1}\right): 3421(\mathrm{O}-\mathrm{H}) ; 1378(\mathrm{C}-\mathrm{N}) ; 1226(\mathrm{C}-\mathrm{O}) ; 1691$ $(\mathrm{C}=\mathrm{O})$; UV/Vis: DMSO, $\lambda \mathrm{nm}$ 260, 312, 374, 568.

\section{Results and discussion}

\subsection{Infrared spectra}

The infrared spectra of $[\mathrm{NiL}]$ and $\left[\mathrm{Cu}_{2} \mathbf{L}_{2} \mathbf{H}_{2} \mathbf{O}\right], \mathbf{H}_{2} \mathbf{O}$ were analyzed in the region $4000-500$ $\mathrm{cm}^{-1}$. Figure 1 shows a band at $3435 \mathrm{~cm}^{-1}$ assigned to intermolecular hydrogen bonded $v(\mathrm{OH})$ for [NiL] and band at $3421 \mathrm{~cm}^{-1}$ assigned to the $\mathrm{OH}$ vibration of aqua and coordinated water molecular for $\left[\mathrm{Cu}_{2} \mathbf{L}_{2} \mathrm{H}_{2} \mathrm{O}\right], \mathrm{H}_{2} \mathrm{O}$. The bands due to lactone carbonyl $v(\mathrm{C}=\mathrm{O})$ and $v(\mathrm{C}-\mathrm{O})$ were found at 1700 $\mathrm{cm}^{-1}$ and $1226 \mathrm{~cm}^{-1}$ (for [NiL] [30-32]) and $1691 \mathrm{~cm}^{-1}$ and $1226 \mathrm{~cm}^{-1}$ (for $\left[\mathbf{C u}_{2} \mathbf{L}_{2} \mathbf{H}_{2} \mathbf{O}\right.$ ], $\mathbf{H}_{2} \mathbf{O}$ $[33,34])$. However, the absorption bands appearing at 1560 and $1378 \mathrm{~cm}^{-1}$ are assigned to the $v(\mathrm{C}=\mathrm{N})$ stretching for both complexes respectively. Lower frequency region above 694 and 594 $\mathrm{cm}^{-1}$ in the spectra of [NiL] $[15,35]$ and 625 and $567 \mathrm{~cm}^{-1}$ in the spectra of the $\left[\mathrm{Cu}_{2} \mathrm{~L}_{2} \mathrm{H}_{2} \mathrm{O}\right], \mathrm{H}_{2} \mathrm{O}$ were tentatively assigned to $v(\mathrm{M}-\mathrm{N})$ and $v(\mathrm{M}-\mathrm{O})$ vibrations.

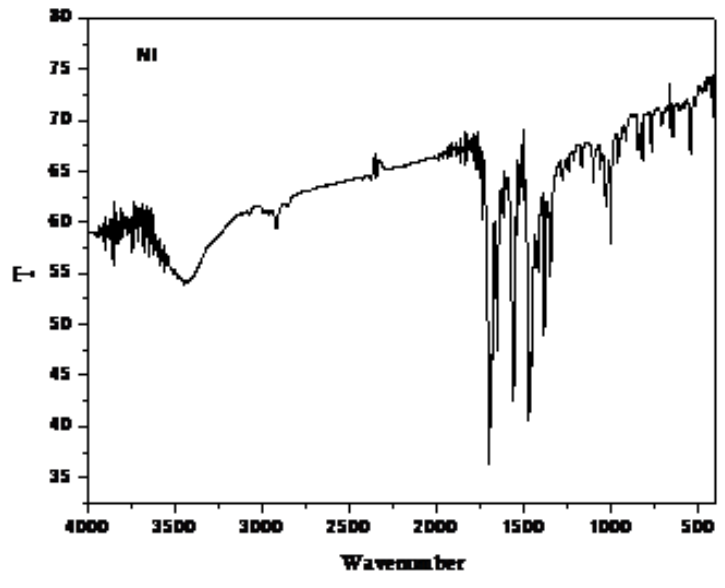

(a)

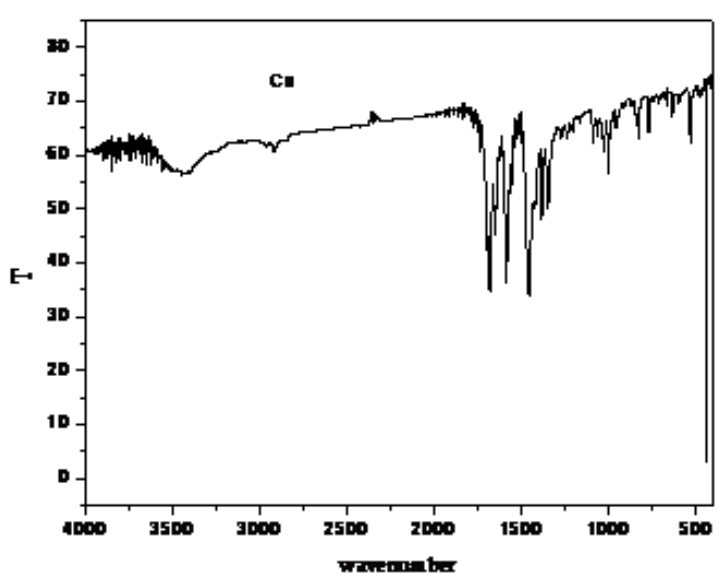

(b)

Fig. 1. Infrared spectrum of (a) $[\mathrm{NiL}]$ and (b) $\left[\mathrm{Cu}_{2} \mathbf{L}_{2} \mathrm{H}_{2} \mathrm{O}\right], \mathrm{H}_{2} \mathrm{O}$.

\subsection{Electronic absorption spectra}

The formation of the metal complexes was also confirmed by UV-vis analysis since their electronic spectra, recorded as DMSO solution in the wavelength range 800-200 $\mathrm{nm}$. For the [NiL] 
complex $\lambda_{\max }$ were observed at $281,310,370$ and $575 \mathrm{~nm}$ assignable to $\pi \rightarrow \pi^{*}, \mathrm{n} \rightarrow \pi^{*}$ and metal to ligand (MLCT) charge transfer transitions, respectively [36,37]. The last peak located at $575 \mathrm{~nm}$ obtained with a concentration of $10^{-3} \mathrm{M}$ was ascribed to the $\mathrm{d}-\mathrm{d}$ electronic transitions which are usually known by their weaker intensities [38].

$\left[\mathrm{Cu}_{2} \mathbf{L}_{2} \mathbf{H}_{2} \mathbf{O}\right], \mathbf{H}_{2} \mathbf{O}$ complex gave four bands at $\lambda_{\max }$ at 260, 312, 374 and $568 \mathrm{~nm}$ assigned to $\pi \rightarrow \pi^{*}, \mathrm{n} \rightarrow \pi^{*}$, metal to ligand (MLCT) charge transfer and d-d transitions. These results are in good agreement with the literature $[39,40]$.

\subsection{X-ray crystal structure}

\section{Crystal structure of [NiL]}

The main crystal parameters are reported in Table 1. The structure of one structural unit and atoms numbering scheme are given in Figure 2. The complex [NiL] is crystallized in a monoclinic system in $\mathrm{P} 2{ }_{1} / \mathrm{c}$ space group and with a four unit per cell $(\mathrm{Z}=4)$. The complex has distorted square-planar geometry connected via two phenolic oxygen $\mathrm{O}_{1}$ and $\mathrm{O}_{4}$ and imine nitrogen $\mathrm{N}_{1}$ and $\mathrm{N}_{2}$ atoms in $\mathrm{E}$ configuration around the $\mathrm{C}_{17}-\mathrm{C}_{18}$ bond, with an average of $92.92^{\circ}$ in the six-membered metallocycle and $89.32^{\circ}$ in the five membered metallocycle.

The two (dha) rings of the complex are not coplanar with the above coordination plane $\left(\mathrm{O}_{1} \mathrm{~N}_{2} \mathrm{~N}_{1} \mathrm{O}_{4}\right)$ and make dihedral angle of $13.61^{\circ}$. The distances between the coordinated nitrogen and oxygen atoms and the metal center do not significantly differ (Table 2), and they are similar to the values found in the $\mathrm{Ni}^{\mathrm{II}}-\mathrm{N}, \mathrm{N}$ '-bis(salicylaldehyde) ethylenediimine complex (Ni-O)=1.83 $\mathrm{A}$, (Ni$\mathrm{N})=1.86 \AA[41]$, in the $\left[\mathrm{NiL}, \mathrm{H}_{2} \mathrm{O}\right](\mathrm{Ni}-\mathrm{O})=1.833(4) \AA,(\mathrm{Ni}-\mathrm{N})=1.856(4) \AA[42]$. The bond angles $\mathrm{O}_{1}-\mathrm{Ni}-\mathrm{O}_{4}, \mathrm{O}_{1}-\mathrm{Ni}-\mathrm{N}_{2}, \mathrm{~N}_{2}-\mathrm{Ni}-\mathrm{N}_{1}, \mathrm{O}_{4}-\mathrm{Ni}_{1}-\mathrm{N}_{1}$ are 84.90(10), 93.17(11), 89.33(12) and 92.64(13) degrees respectively. The atoms $\mathrm{N}_{1}, \mathrm{~N}_{2}, \mathrm{O}_{1}$ and $\mathrm{O}_{4}$ are coplanar and define the basal plane. The maximum of deviation is given by the oxygen atoms $(0.027 \AA)$.

In the crystal, individual molecules are packed in layers parallel, in which the molecules of the second layer are oriented in a nearly perpendicular fashion to each other (Figure 3a), each two layers are linked by intermolecular hydrogen bonds between adjacent molecules (Figure 3b).

\section{Crystal structure of $\left[\mathrm{Cu}_{2} \mathrm{~L}_{2} \mathrm{H}_{2} \mathrm{O}\right], \mathrm{H}_{2} \mathrm{O}$}

The main crystal parameters are reported in Table 1. The bond distances and angles are listed in Table 2 and the structure and the numbering scheme are given in Figure 2. The complex $\left[\mathrm{Cu}_{2} \mathrm{~L}_{2} \mathrm{H}_{2} \mathrm{O}\right], \mathrm{H}_{2} \mathrm{O}$ crystallizes in a triclinic system with a $\mathrm{P}-1$ space group and we note the presence of two molecules per unit cell. $\left[\mathrm{Cu}_{2} \mathrm{~L}_{2} \mathrm{H}_{2} \mathrm{O}\right], \mathrm{H}_{2} \mathrm{O}$ is binuclear, the structure reveals that the two $\mathrm{Cu}$ (II) 
center is " $4+1$ " coordinated, exhibiting a highly distorted tetragonal pyramid geometry in which the basal plane is occupied by two oxygen atoms from the phenolates and two nitrogen atoms from the imine groups of the ligand, the axial position of $\mathrm{Cu} 1$ is occupied by $\mathrm{O} 1 \mathrm{w}$ atom of water molecular and one pyrone oxygen from another moiety, in axial positions from $\mathrm{Cu} 2$. One Molecule of water links the two ligands.

The distances between nitrogen and oxygen atoms and the metal center (Table 2) are similar to the values found in the $\left[\mathrm{Cu}(\mathrm{dha})_{2} \mathrm{en}\left(\mathrm{H}_{2} \mathrm{O}\right)\right]$ [41] and $\mathrm{Cu}^{\mathrm{II}}$ (N,N'-bis(salicylaldehyde)-2,2'biphenyldiimine [42]. The bond angles O2-Cu1-O1, N2-Cu1-N1, O22-Cu2-O11, N22-Cu2-N11 are $88.85^{\circ}, 88.01^{\circ}, 88.08^{\circ}$ and $87.47^{\circ}$ respectively. The $\mathrm{O}-\mathrm{Cu}-\mathrm{N}$ angles in the basal plane are of 176.97 and $170.67^{\circ}$ for $\mathrm{Cu} 1$ and 177.30 and 177.46 for $\mathrm{Cu} 2$ showing a small distortion in the geometry.

In fact, the packing analysis in the unit cell shows that two molecules of the complex are not close one to another, and a dimeric structure (face to face) is formed considering the weak interdimer electrostatic Cu2-O6 (pyrone) (Figure 4(a,b)). In the dimer, the $\mathrm{Cu} . . \mathrm{Cu}$ distances is of $6.069(3) \AA$, which is significantly long than those distances found in the bis(salicylaldehydato) $\mathrm{Cu}$ (II) complex $(4.05 \AA)[43,44]$. Indeed this $\mathrm{Cu}$... Cu distance is comparable to those distances found in many dinuclear $\mathrm{Cu}(\mathrm{II})$ oxygen bridged complexes [45-48]. A water molecule serves as a link between the two ligands via two hydrogen bonds.

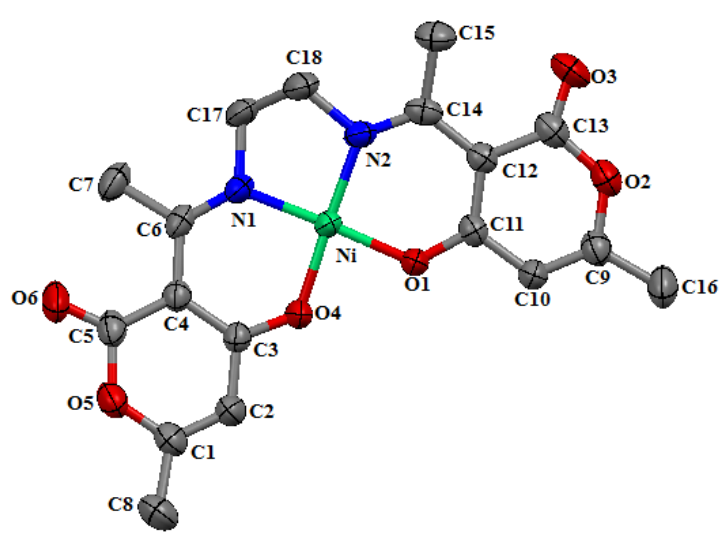

(a)

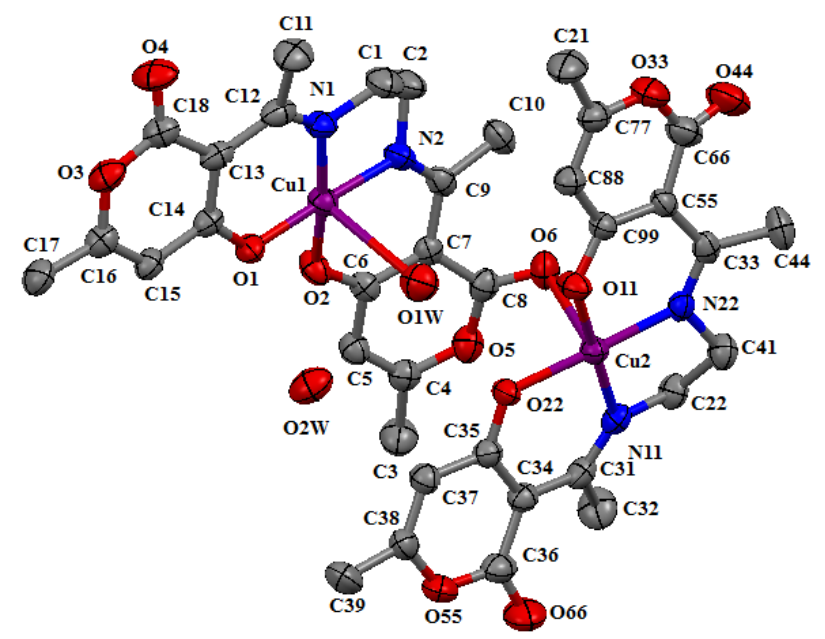

(b)

Fig. 2. The molecular structure of the $[\mathrm{NiL}]$ (a) and $\left[\mathrm{Cu}_{2} \mathbf{L}_{2} \mathbf{H}_{2} \mathrm{O}\right], \mathrm{H}_{2} \mathrm{O}$ (b). 


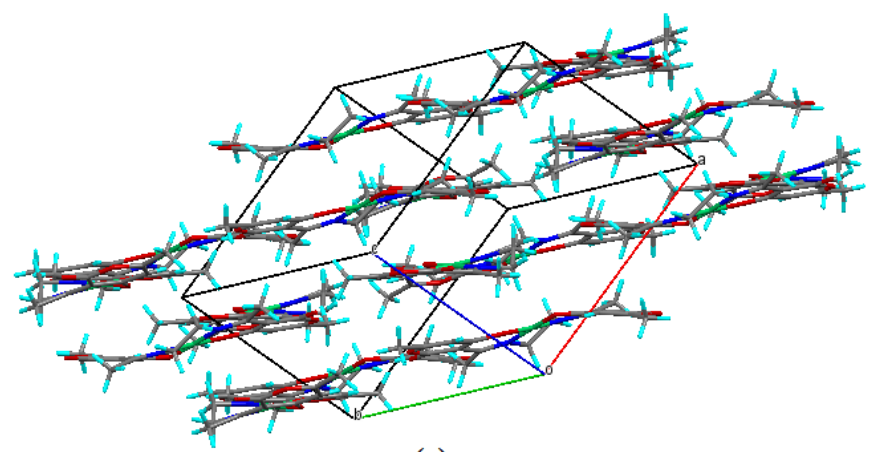

(a)

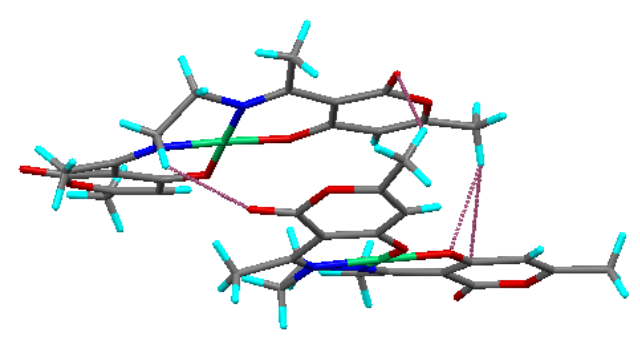

(b)

Fig. 3. Cell packing (a) and hydrogen bonding (b) for [NiL].

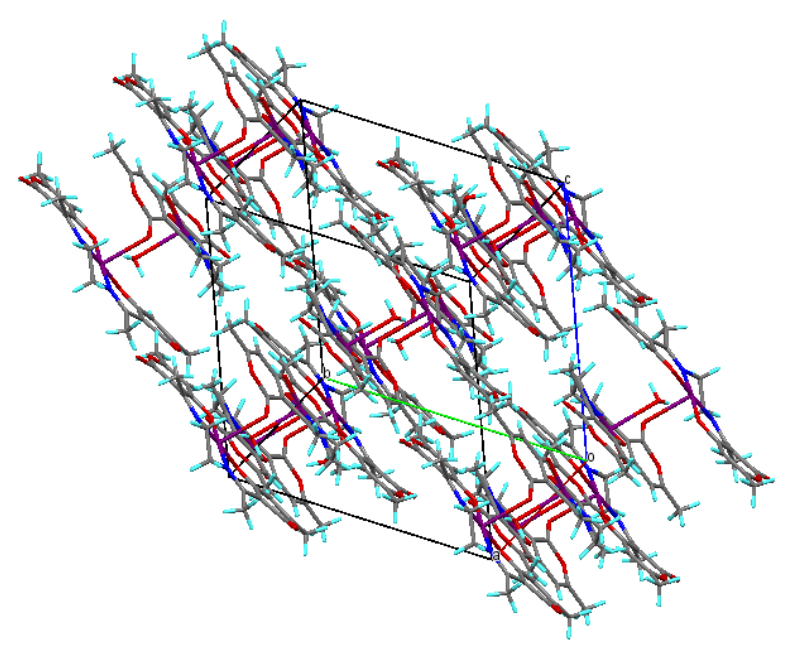

(a)

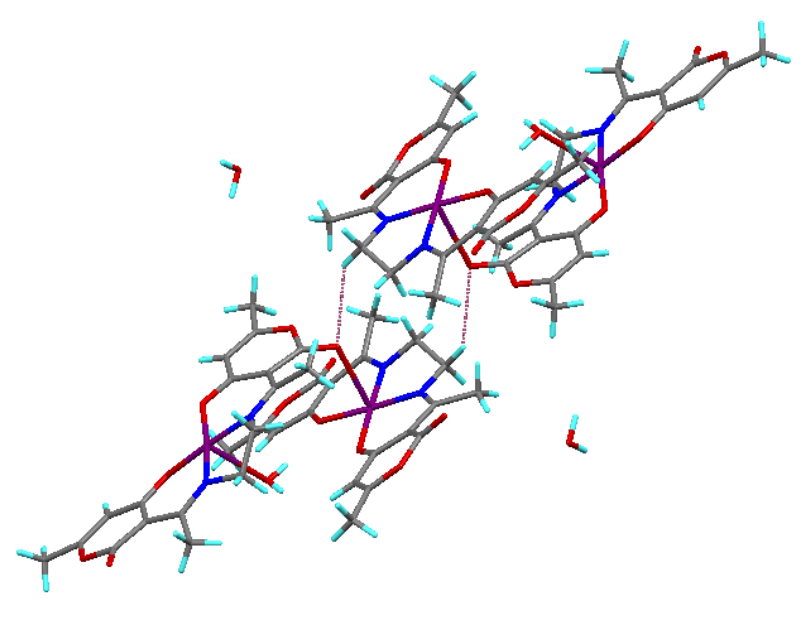

(b)

Fig. 4. Cell packing (a) and hydrogen bonding (b) for $\left[\mathrm{Cu}_{2} \mathbf{L}_{2} \mathbf{H}_{2} \mathrm{O}\right], \mathbf{H}_{2} \mathbf{O}$. 
Table 1. Crystallographic data for [NiL] and $\left[\mathrm{Cu}_{2} \mathbf{L}_{2} \mathbf{H}_{2} \mathrm{O}\right], \mathbf{H}_{2} \mathbf{O}$.

\begin{tabular}{|c|c|c|}
\hline Compound & {$[\mathrm{NiL}]$} & {$\left[\mathrm{Cu}_{2} \mathrm{~L}_{2} \mathrm{H}_{2} \mathrm{O}\right], \mathrm{H}_{2} \mathrm{O}$} \\
\hline Molecular formula & $\mathrm{C}_{18} \mathrm{H}_{18} \mathrm{~N}_{2} \mathrm{NiO}_{6}$ & $\mathrm{C}_{36} \mathrm{H}_{40} \mathrm{Cu}_{2} \mathrm{~N}_{4} \mathrm{O}_{14}$ \\
\hline Molecular weight & 417.05 & 879.80 \\
\hline Temperature (K) & 293 & 293 \\
\hline Radiation & $\operatorname{Mo} K \alpha \operatorname{radiation}(\lambda=0.71073 \AA)$ & Mo $K \alpha(\lambda=0.71073 \AA)$ \\
\hline Crystal system & Monoclinic & Triclinic \\
\hline Crystal colour & Orange & Bleu \\
\hline Space group & $\mathrm{P} 2{ }_{1} / \mathrm{c}$ & P-1 \\
\hline $\mathrm{a}\left(\mathrm{A}^{\circ}\right)$ & $12.905(5)$ & $0.601(5)$ \\
\hline$b\left(A^{\circ}\right)$ & $13.575(5)$ & $12.928(5)$ \\
\hline$c\left(A^{\circ}\right)$ & $10.167(5)$ & $14.778(5)$ \\
\hline $\mathrm{Alpha}^{\circ}$ & $90.000(5)$ & $70.230(5)^{\circ}$ \\
\hline Beta $^{\circ}$ & $104.374(5)$ & $88.950(5)^{\circ}$ \\
\hline $\mathrm{Gamma}^{\circ}$ & $90.000(5)$ & $74.203(5)^{\circ}$ \\
\hline $\mathrm{Z}$ & 4 & 2 \\
\hline $\mathrm{V} / \mathrm{A}^{3}$ & $1725.4(13)$ & $1827.9(13)$ \\
\hline $\mathrm{D}_{\text {calc }}\left(\mathrm{g} \mathrm{cm}^{-3}\right)$ & 1.606 & 1.599 \\
\hline Crystal description & needle & needle \\
\hline Absorption coefficient $\left(\mathrm{mm}^{-1}\right)$ & 1.16 & 1.24 \\
\hline $\mathrm{F}(000)$ & 864 & 908 \\
\hline Reflections collected /unique & $12472 / 3543\left[R_{\mathrm{int}}=0.038\right]$ & $20580 / 11511\left[R_{\text {int }}=0.049\right]$ \\
\hline Range/indices (h,k,l) & $-15,16 ;-16,13 ;-12,12$ & $-7,15 ;-19,19 ;-20,20$ \\
\hline Teta $_{\text {limit }}$ & $1.6-26.4$ & $1.6-26.4$ \\
\hline No.of observed data, $\mathrm{I}>2 \sigma(\mathrm{I})$ & 2555 & 7849 \\
\hline No.of variables & 252 & 519 \\
\hline No.of restraints & 2 & 4 \\
\hline Goodness of fit on $\mathrm{F}^{2}$ & 1.041 & 1.068 \\
\hline Largestdiff. Peak and hole $\left(\mathrm{eA}^{-3}\right)$ & 0.37 and -0.35 & 2.03 and -1.54 \\
\hline$R\left[F^{2}>2 \sigma\left(F^{2}\right)\right]$ & 0.043 & 0.077 \\
\hline$w R\left(F^{2}\right)$ & 0.128 & 0.243 \\
\hline Maximum $\Delta / \sigma$ & $<0.001$ & 0.276 \\
\hline
\end{tabular}


Table 2. Selected bond distances $(\AA)$ and angles $\left({ }^{\circ}\right)$ for $[\mathrm{NiL}]$ and $\left[\mathrm{Cu}_{2} \mathbf{L}_{2} \mathrm{H}_{2} \mathrm{O}\right], \mathrm{H}_{2} \mathrm{O}$ complexes.

\begin{tabular}{|c|c|c|c|}
\hline \multicolumn{2}{|c|}{ Bond lengths $(\AA)$} & \multicolumn{2}{|c|}{ Bond angles $\left({ }^{\circ}\right)$} \\
\hline \multicolumn{4}{|l|}{$[\mathrm{NiL}]$} \\
\hline $\mathrm{Ni}-\mathrm{O} 1$ & $1.832(2)$ & $\mathrm{O} 1-\mathrm{Ni}-\mathrm{O} 4$ & $84.90(10)$ \\
\hline $\mathrm{Ni}-\mathrm{O} 4$ & $1.839(2)$ & $\mathrm{O} 1-\mathrm{Ni}-\mathrm{N} 2$ & $93.17(11)$ \\
\hline $\mathrm{Ni}-\mathrm{N} 1$ & $1.854(3)$ & $\mathrm{O} 4-\mathrm{Ni}-\mathrm{N} 1$ & $92.64(11)$ \\
\hline $\mathrm{Ni}-\mathrm{N} 2$ & $1.851(3)$ & $\mathrm{N} 2-\mathrm{Ni}-\mathrm{N} 1$ & $89.33(12)$ \\
\hline $\mathrm{N} 1-\mathrm{C} 6$ & $1.300(5)$ & $\mathrm{C} 3-\mathrm{O} 4-\mathrm{Ni}$ & $126.5(2)$ \\
\hline $\mathrm{N} 1-\mathrm{C} 17 \quad 1$ & $1.476(4)$ & $\mathrm{C} 11-\mathrm{O} 1-\mathrm{Ni}$ & $128.20(2)$ \\
\hline $\mathrm{N} 2-\mathrm{C} 14 \quad 1$ & $1.306(4)$ & $\mathrm{C} 6-\mathrm{N} 1-\mathrm{Ni}$ & $129.7(2)$ \\
\hline $\mathrm{N} 2-\mathrm{C} 18 \quad 1$ & $1.486(4)$ & $\mathrm{C} 17-\mathrm{N} 1-\mathrm{Ni}$ & 109.08 (2) \\
\hline $\mathrm{O} 1-\mathrm{C} 111$ & $1.283(4)$ & $\mathrm{C} 14-\mathrm{N} 2-\mathrm{Ni}$ & $129.9(2)$ \\
\hline \multirow[t]{7}{*}{$\mathrm{O} 4-\mathrm{C} 3$} & $1.284(4)$ & $\mathrm{C} 18-\mathrm{N} 2-\mathrm{Ni}$ & $100.0(2)$ \\
\hline & & $\mathrm{O} 4-\mathrm{Ni}-\mathrm{N} 2$ & $177.54(12)$ \\
\hline & & $\mathrm{O} 1-\mathrm{Ni}-\mathrm{N} 1$ & $176.99(12)$ \\
\hline & & $\mathrm{C} 14-\mathrm{N} 2-\mathrm{C} 18$ & $120.0(3)$ \\
\hline & & $\mathrm{C} 6-\mathrm{N} 1-\mathrm{C} 17$ & $120.4(3)$ \\
\hline & & $\mathrm{N} 1-\mathrm{C} 17-\mathrm{C} 18$ & 107.5(3) \\
\hline & & $\mathrm{N} 2-\mathrm{C} 18-\mathrm{C} 17$ & 107.7(3) \\
\hline \multicolumn{4}{|c|}{$\left[\mathrm{Cu}_{2} \mathrm{~L}_{2} \mathrm{H}_{2} \mathrm{O}\right], \mathrm{H}_{2} \mathrm{O}$} \\
\hline $\mathrm{Cu} 1-\mathrm{O} 21$ & $1.903(2)$ & $\mathrm{O} 2-\mathrm{Cu} 1-\mathrm{O} 1$ & $88.85(11)$ \\
\hline $\mathrm{Cu} 1-\mathrm{O} 11$ & $1.914(3)$ & $\mathrm{O} 1-\mathrm{Cu} 1-\mathrm{N} 1$ & $91.83(12)$ \\
\hline $\mathrm{Cu} 1-\mathrm{N} 21$ & $1.931(3)$ & $\mathrm{O} 1-\mathrm{Cu} 1-\mathrm{N} 2$ & $176.97(12)$ \\
\hline $\mathrm{Cu} 1-\mathrm{N} 11$ & $1.936(3)$ & $\mathrm{O} 2-\mathrm{Cu} 1-\mathrm{N} 1$ & $170.68(13)$ \\
\hline $\mathrm{Cu} 1-\mathrm{O} 1 \mathrm{w}$ & W $2.705(3)$ & $\mathrm{N} 2-\mathrm{Cu} 1-\mathrm{N} 1$ & $88.01(13)$ \\
\hline $\mathrm{Cu} 2-\mathrm{O} 22$ & $1.910(3)$ & $\mathrm{O} 2-\mathrm{Cu} 1-\mathrm{N} 2$ & $91.80(12)$ \\
\hline $\mathrm{Cu} 2-\mathrm{O} 11$ & $1.910(2)$ & $\mathrm{C} 9-\mathrm{N} 2-\mathrm{Cu} 1$ & $128.4(2)$ \\
\hline $\mathrm{Cu} 2-\mathrm{N} 22$ & $1.930(3)$ & $\mathrm{C} 2-\mathrm{N} 2 \mathrm{Cu} 1$ & 109.5(3) \\
\hline $\mathrm{Cu} 2-\mathrm{N} 11$ & $1.948(3)$ & $\mathrm{C} 14-\mathrm{O} 1 \mathrm{Cu} 1$ & $126.7(2)$ \\
\hline $\mathrm{Cu} 2-\mathrm{O} 5$ & $2.699(3)$ & $\mathrm{C} 6-\mathrm{O} 2-\mathrm{Cu} 1$ & $124.2(2)$ \\
\hline $\mathrm{N} 22-\mathrm{C} 33$ & $1.296(4)$ & $\mathrm{C} 12-\mathrm{N} 1-\mathrm{Cu} 1$ & $129.5(3)$ \\
\hline $\mathrm{N} 22-\mathrm{C} 41$ & $1.478(4)$ & $\mathrm{C} 1-\mathrm{N} 1-\mathrm{Cu} 1$ & $108.8(2)$ \\
\hline $\mathrm{N} 11-\mathrm{C} 31$ & $1.293(5)$ & $\mathrm{O} 22-\mathrm{Cu} 2-\mathrm{N} 22$ & $177.30(11)$ \\
\hline $\mathrm{N} 11-\mathrm{C} 22$ & $1.470(5)$ & $\mathrm{O} 22-\mathrm{Cu} 2-\mathrm{O} 11$ & $88.08(11)$ \\
\hline $\mathrm{C} 12-\mathrm{N} 1$ & $1.300(5)$ & $\mathrm{O} 11-\mathrm{Cu} 2-\mathrm{N} 22$ & $92.63(11)$ \\
\hline $\mathrm{N} 2-\mathrm{C} 9$ & $1.298(5)$ & $\mathrm{O} 22-\mathrm{Cu} 2-\mathrm{N} 11$ & 91.94(11) \\
\hline $\mathrm{N} 2-\mathrm{C} 2$ & $1.468(4)$ & $\mathrm{O} 11-\mathrm{Cu} 2-\mathrm{N} 11$ & $177.48(12)$ \\
\hline
\end{tabular}




\begin{tabular}{|llll|}
\hline $\mathrm{N} 1-\mathrm{C} 1$ & $1.478(5)$ & $\mathrm{N} 22-\mathrm{Cu} 2-\mathrm{N} 11$ & $87.47(12)$ \\
$\mathrm{O} 1-\mathrm{C} 14$ & $1.280(4)$ & $\mathrm{C} 99-\mathrm{O} 1-\mathrm{Cu} 2$ & $125.7(2)$ \\
$\mathrm{O} 2-\mathrm{C} 6$ & $1.283(4)$ & $\mathrm{C} 35-\mathrm{O} 22-\mathrm{Cu} 2$ & $126.4(2)$ \\
$\mathrm{O} 22-\mathrm{C} 35$ & $1.274(4)$ & $\mathrm{C} 33-\mathrm{N} 22-\mathrm{Cu} 2$ & $129.4(2)$ \\
$\mathrm{O} 11-\mathrm{C} 99$ & $1.279(4)$ & $\mathrm{C} 41-\mathrm{N} 22-\mathrm{Cu} 2$ & $109.8(2)$ \\
$\mathrm{O} 6-\mathrm{C} 8$ & $1.215(4)$ & $\mathrm{C} 31-\mathrm{N} 11-\mathrm{Cu} 2$ & $129.0(2)$ \\
& & $\mathrm{C} 22-\mathrm{N} 11-\mathrm{Cu} 2$ & $108.2(2)$ \\
\hline
\end{tabular}

\subsection{Electrochemical studies}

Curve A (Figure 5) shows the cyclic voltammograms of [NiL] complex in DMSO solution in the potential ranges of +1.8 to $-2.2 \mathrm{~V}$. The cyclovoltammograms of the nickel complex display quasi-reversible reductive response $\left(\mathrm{Ep}_{\mathrm{c}}\right.$ at $\left.-1.46 \mathrm{~V}\right)$ during cathodic scan, attributed to the $\mathrm{Ni}{ }^{\mathrm{II}} / \mathrm{Ni}^{\mathrm{I}}$ couple. During the anodic potential scan, the complex shows an irreversible oxidative response at $+1.39 \mathrm{~V}$ that may be assigned to the oxidation of the Schiff base.

As can be seen also, a well-defined redox peak with formal potential of $-1.41 \mathrm{~V}$ versus SCE electrode was observed (Figure 5B). These anodic and cathodic peaks are due to redox reaction of the $\mathrm{Ni}(\mathrm{II}) / \mathrm{Ni}(\mathrm{I})$ couple at the electrode surface. The potential was cycled between -0.7 and $-1.8 \mathrm{~V}$ for the $\mathrm{Ni}(\mathrm{II}) / \mathrm{Ni}(\mathrm{I})$ redox system in $\mathrm{DMSO}$ solution and a large peak-to-peak separation $(\Delta \mathrm{E}=110$ $\mathrm{mV}$ ), indicating a quasi-reversible nature for the $\mathrm{Ni}^{\mathrm{II}} / \mathrm{Ni}^{\mathrm{I}}$ reductive response. The electrochemical behavior and the data are in agreement with those reported for related complexes [49].

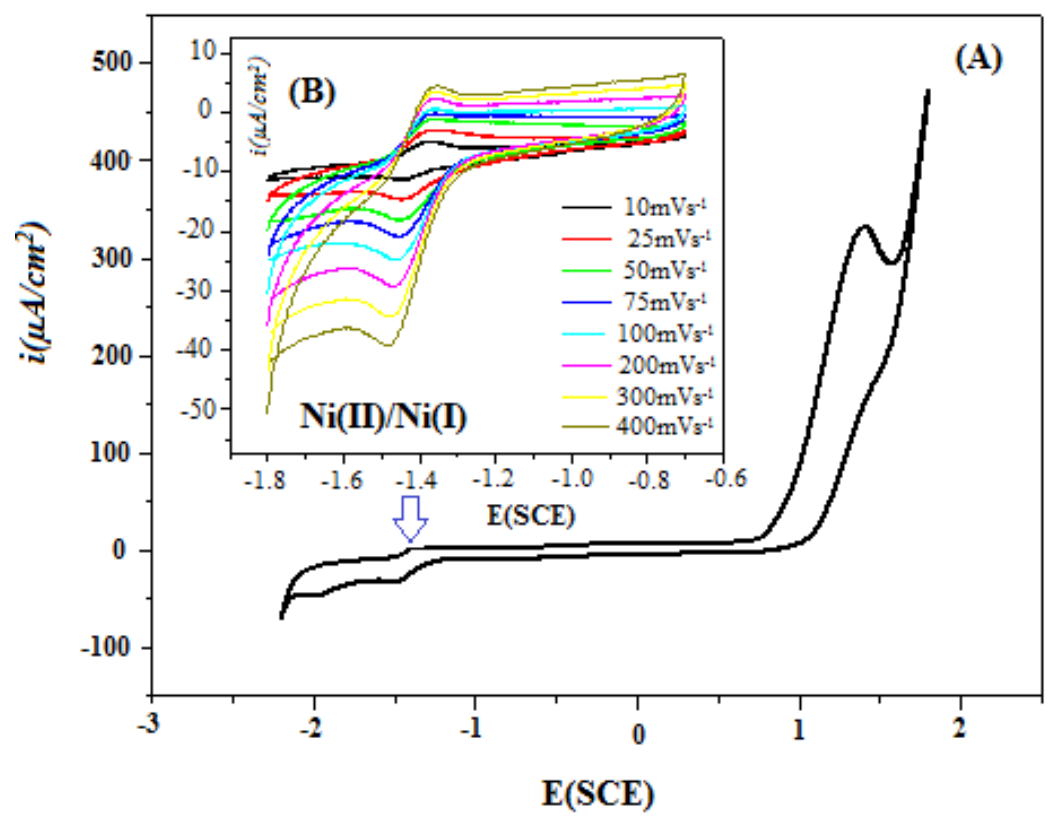

Fig. 5. Cyclic voltammogram of $[\mathrm{NiL}]$ in the range +1.8 to $-2.2 \mathrm{~V}(\mathbf{A})$; and in the range -0.7 to -1.8 at different scan rates for (B). 
Figure 6 shows the cyclic voltammograms of $\left[\mathbf{C u}_{2} \mathbf{L}_{2} \mathbf{H}_{2} \mathbf{O}\right], \mathbf{H}_{2} \mathbf{O}$ complex in DMSO solution in the potential ranges of +1.8 to $-2.2 \mathrm{~V}$. The cyclovoltammogram of the copper complex display irreversible reductive responses ( $\mathrm{Ep}_{\mathrm{c}}$ at -0.95 and $-1.55 \mathrm{~V}$, respectively) during cathodic scan, attributed to the $\mathrm{Cu}{ }^{\mathrm{II}} / \mathrm{Cu}^{\mathrm{I}}$ couple. During the anodic potential scan, the complex shows an oxidative response at $-0.10 \mathrm{~V}$ with very thin size (Figure $6 \mathrm{~B}$ ) and high peak current and irreversible oxidative responses at $+1.24 \mathrm{~V}$ (Figure $6 \mathrm{~A}$ ). The response at $-0.10 \mathrm{~V}$ is typical of the anodic stripping of copper. Therefore, it may be inferred that the $\mathrm{Cu}(\mathrm{II})$ complex undergo reduction to their respective $\mathrm{Cu}(\mathrm{I})$ complex which subsequently undergo disproportionation to $\mathrm{Cu}^{0}$ and $\mathrm{Cu}^{\mathrm{II}}$. The instability of the $\mathrm{Cu}(\mathrm{I})$ complex is in agreement with the literature [50]. The oxidative responses around $1.24 \mathrm{~V}$ may be due to the $\mathrm{Cu}^{\mathrm{II}} / \mathrm{Cu}^{\mathrm{III}}$ couple.

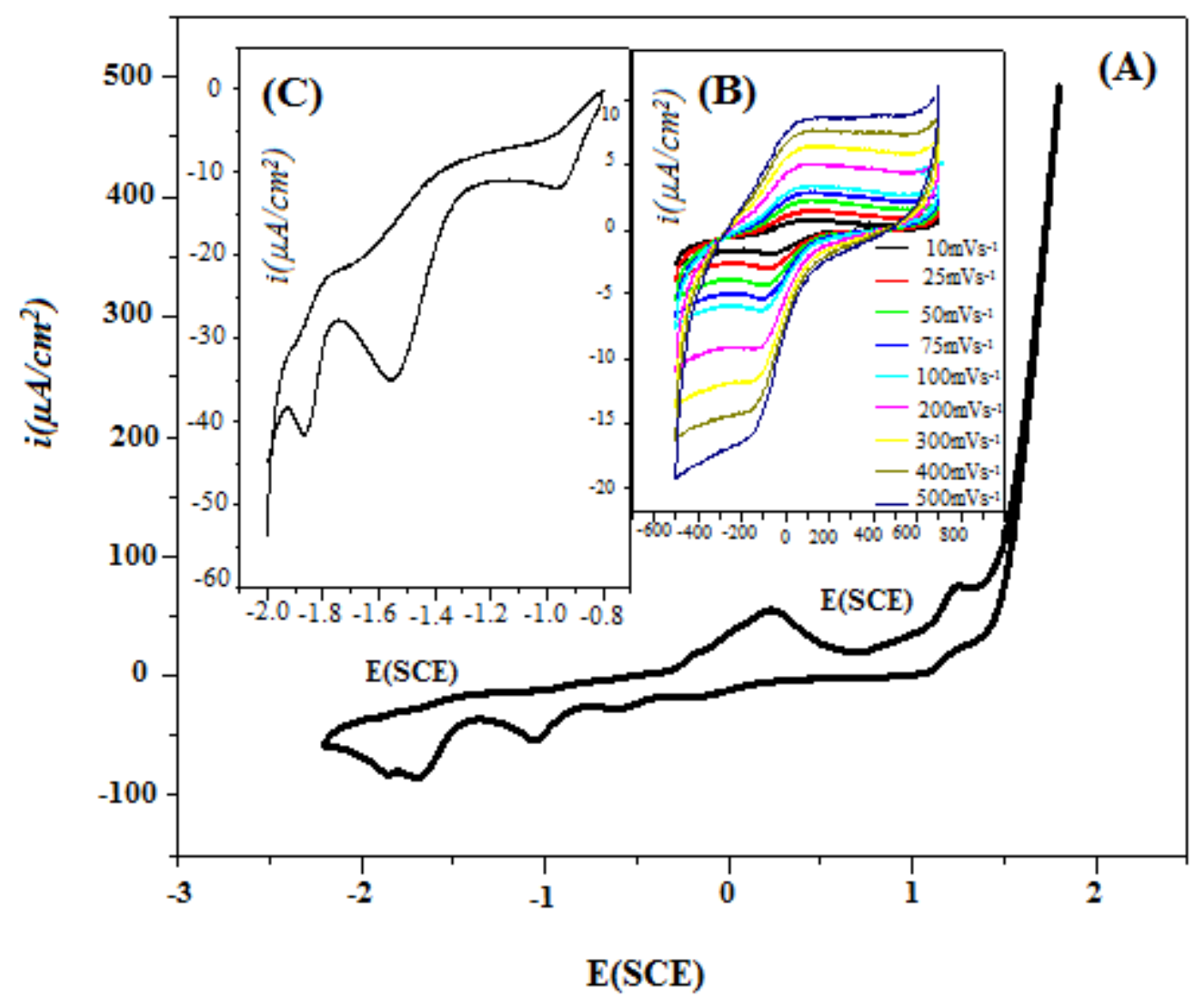

Fig. 6. Cyclic voltammogram of $\left[\mathrm{Cu}_{2} \mathrm{~L}_{2} \mathrm{H}_{2} \mathrm{O}\right], \mathrm{H}_{2} \mathrm{O}$ in the range +1.8 to $-2.2 \mathrm{~V}$ (A); -0.6 to -2.0 (C) and +0.5 to -0.5 at different scan rates for $(\mathrm{B})$.

\section{Computational methods}

The ground state optimizations of complexes [NiL] and $\left[\mathrm{Cu}_{2} \mathbf{L}_{2} \mathbf{H}_{2} \mathrm{O}\right], \mathrm{H}_{2} \mathrm{O}$ have been carried out in the framework of DFT using the global hybrid B3LYP functional in combination with 6-311G (d,p) basis sets for C,N,O and H, and LANL2DZ pseudo potential and basis set [51] for Ni 
and $\mathrm{Cu}$ metals. In the following, Gen refers to Lanl2dz (for $\mathrm{Cu}, \mathrm{Ni}$ ) and 6-311G(d,p) (for N,O,H,C). Electronic excited states calculations have been performed in the framework of the time-dependent density functional theory (TDDFT) using B3LYP and the Gen basis set. Excited states and charge transfer character of electronic transitions were characterized by plotting the electron density and using the Natural transition orbitals (NTOs) [52,53].

\subsection{Optimized structure}

The optimization structures and the geometrical parameters such as bond lengths, and bond angles are given in Table 3. Concerning the complex of [NiL] the metal-ligand bond distances are slightly longer than the experimental values within 0.014-0.034 $\AA$ range. The calculated bond distances of $\mathrm{Ni}-\mathrm{O}$ and $\mathrm{Ni}-\mathrm{N}$ are 1.853 and $1.880 \AA$ respectively compared to the experimental values of 1.832-1.839 $\AA$ and $1.854 \AA$ respectively. The binuclear complex of $\left[\mathrm{Cu}_{2} \mathbf{L}_{2} \mathbf{H}_{2} \mathbf{O}\right], \mathrm{H}_{2} \mathrm{O}$ is characterized by its asymmetric unit containing one complex molecule and one water molecule. The structure reveals that the two $\mathrm{Cu}$ (II) center is " $4+1$ " coordinated, exhibiting a distorted tetragonal pyramid geometry in which the basal plane is occupied by two oxygen atoms from the phenolates and two nitrogen atoms from the imine groups of the ligand, the axial position of $\mathrm{Cu} 1$ is occupied by $\mathrm{O} 1 \mathrm{w}$ atom of water molecular and one pyrone oxygen from another moiety, in axial positions from $\mathrm{Cu} 2$. The $\left[\mathrm{Cu}_{2} \mathbf{L}_{2} \mathbf{H}_{2} \mathbf{O}\right], \mathbf{H}_{2} \mathbf{O}$ complex has a square-planar geometry connected via two phenolic oxygen $\mathrm{O}_{2}$ and $\mathrm{O}_{5}$ and imine nitrogen $\mathrm{N}_{8}$ and $\mathrm{N}_{11}$. For [NiL] the calculated values are in good agreement with the experiments, since all differences between the theoretical and experimental bond lengths are in 0.034-0.08 $\AA$. The calculated ligand-metal-ligand bond angles for the two complexes are almost similar to the experimental values with slight deviations within for $0.09-1.85^{\circ}$ of the complex [NiL] and $0.41^{\circ}-5.28^{\circ}$ for the complex $\left[\mathrm{Cu}_{2} \mathrm{~L}_{2} \mathrm{H}_{2} \mathrm{O}\right], \mathrm{H}_{2} \mathrm{O}$. 
Table 3. Selected bond lengths $(\AA)$ and angles $\left({ }^{\circ}\right)$ for $\left[\mathbf{C u}_{2} \mathbf{L}_{2} \mathbf{H}_{2} \mathbf{O}\right], \mathbf{H}_{2} \mathbf{O}$ and $[\mathrm{NiL}]$.

\begin{tabular}{|c|c|c|}
\hline & B3LYP/Gen & Exp \\
\hline \multicolumn{3}{|c|}{ [NiL] } \\
\hline \multicolumn{3}{|l|}{ Bond length $(\AA ̊)$} \\
\hline $\mathrm{Ni}-\mathrm{O} 2$ & 1.853 & 1.832 \\
\hline $\mathrm{Ni}-\mathrm{O} 5$ & 1.853 & 1.839 \\
\hline Ni-N11 & 1.888 & 1.854 \\
\hline $\mathrm{Ni}-\mathrm{O} 2$ & 1.853 & 1.832 \\
\hline \multicolumn{3}{|l|}{ Angles $\left(^{\circ}\right)$} \\
\hline O5-Ni- N11 & 92.02 & 93.17 \\
\hline $\mathrm{O} 2-\mathrm{Ni}-\mathrm{N} 8$ & 92.02 & 92.64 \\
\hline $\mathrm{O} 5-\mathrm{Ni}-\mathrm{O} 2$ & 86.75 & 84.90 \\
\hline N8- Ni -N11 & 89.24 & 89.33 \\
\hline \multicolumn{3}{|c|}{$\left[\mathrm{Cu}_{2} \mathrm{~L}_{2} \mathrm{H}_{2} \mathrm{O}\right], \mathrm{H}_{2} \mathrm{O}$} \\
\hline \multicolumn{3}{|l|}{ Bond length $(\AA)$} \\
\hline Cu1- O7 & 1.990 & 1.914 \\
\hline Cu1-O5 & 1.979 & 1.903 \\
\hline Cu1-N17 & 1.994 & 1.936 \\
\hline Cu1-N15 & 2.011 & 1.931 \\
\hline $\mathrm{Cu} 2-\mathrm{O} 8$ & 1.987 & 1.910 \\
\hline $\mathrm{Cu} 2-\mathrm{O} 10$ & 1.975 & 1.910 \\
\hline $\mathrm{Cu} 2-\mathrm{N} 22$ & 1.982 & 1.948 \\
\hline $\mathrm{Cu} 2-\mathrm{N} 24$ & 1.988 & 1.930 \\
\hline \multicolumn{3}{|l|}{ Angles $\left(^{\circ}\right)$} \\
\hline O15-Cu1-O17 & 87.60 & 88.01 \\
\hline N15-Cu1-O5 & 89.98 & 88.95 \\
\hline O5-Cu1-N17 & 94.10 & 88.85 \\
\hline O7-Cu1-N17 & 88.70 & 91.80 \\
\hline O7-Cu1-N15 & 174.94 & 177.3 \\
\hline N17-Cu1-O5 & 173.47 & 170.68 \\
\hline O24-Cu2-N22 & 87.12 & 87.47 \\
\hline N22-Cu2-O8 & 89.98 & 88.95 \\
\hline O10-Cu2-N24 & 88.08 & 91.94 \\
\hline O10-Cu2-N22 & 91.058 & 88.08 \\
\hline N24-Cu2-O8 & 173.48 & 177.48 \\
\hline
\end{tabular}

\subsection{Harmonic vibrational frequencies}

Experimental and calculated IR spectra of $[\mathrm{NiL}]$ and $\left[\mathrm{Cu}_{2} \mathbf{L}_{2} \mathbf{H}_{2} \mathbf{O}\right], \mathbf{H}_{2} \mathbf{O}$ are shown in Figure 7(a,b). A rigorous analysis for modes of vibration with B3LYP level is mentioned in Table 4. The calculated values are globally in good agreement with the experimental data. The experimental FTIR band at $3435 \mathrm{~cm}^{-1}$ assigned to intermolecular hydrogen bonded $v(\mathrm{OH})$ for $\left[\mathrm{Cu}_{2} \mathbf{L}_{2} \mathbf{H}_{2} \mathbf{O}\right], \mathbf{H}_{2} \mathbf{O}$ is calculated at $3432 \mathrm{~cm}^{-1}$ at B3LYP/Gen level. The lactone $\mathrm{v}(\mathrm{C}-\mathrm{O})$ stretch vibration appear in the region $1226 \mathrm{~cm}^{-1}$ in experiment, while it is calculated at $1256 \mathrm{~cm}^{-1}$ for complex [NiL] and $1215 \mathrm{~cm}^{-}$ ${ }^{1}$ for $\left[\mathrm{Cu}_{2} \mathbf{L}_{2} \mathbf{H}_{2} \mathbf{O}\right], \mathbf{H}_{2} \mathbf{O}$. The frequency for carbonyl $v(\mathrm{C}=\mathrm{O})$ has been calculated at $1701 \mathrm{~cm}^{-1}$ for the complex of $\mathrm{Ni}$ and $1694 \mathrm{~cm}^{-1}$ for complex of $\mathrm{Cu}$, in excellent agreement with experimental data 
of $1700 \mathrm{~cm}^{-1}$ and $1691 \mathrm{~cm}^{-1}$ respectively. The experimental data of the $v(\mathrm{C}=\mathrm{N})$ stretching vibration is in $1378 \mathrm{~cm}^{-1}$ for the complex of $\mathrm{Cu}$ metal and $1560 \mathrm{~cm}^{-1}$ for and complex of Ni metal, these bands have been calculated at $1385 \mathrm{~cm}^{-1}$ and $1597 \mathrm{~cm}^{-1}$. The lower frequency region above $594 \mathrm{~cm}^{-}$ 1 for $[\mathrm{NiL}]$ and $567 \mathrm{~cm}^{-1}$ for $\left[\mathrm{Cu}_{2} \mathbf{L}_{2} \mathbf{H}_{2} \mathrm{O}\right], \mathbf{H}_{2} \mathrm{O}$ is the characteristic region for identification of $v(\mathrm{M}-\mathrm{O})$ and $v(\mathrm{M}-\mathrm{N})$ while these bands were computed at $591 \mathrm{~cm}^{-1}$ for complex of $\mathrm{Ni}$ and 577 $\mathrm{cm}^{-1}$ for complex of $\mathrm{Cu}$.

Table 4: Comparison of the experimental and calculated vibrational frequencies $\left(\mathrm{cm}^{-1}\right)$ for $[\mathrm{NiL}]$ and $\left[\mathrm{Cu}_{2} \mathrm{~L}_{2} \mathrm{H}_{2} \mathrm{O}\right], \mathrm{H}_{2} \mathrm{O}$ complexes.

\begin{tabular}{|c|c|c|c|c|}
\hline & {$[\mathrm{NiL}]$} & & {$\left[\mathrm{Cu}_{2} \mathrm{~L}_{2} \mathrm{H}_{2} \mathrm{O}\right.$} & \\
\hline $\begin{array}{l}\text { Assignement } \\
\left(\mathrm{cm}^{-1}\right)\end{array}$ & B3LYP & Exp & B3LYP & Exp \\
\hline $\begin{array}{l}\mathrm{v}\left(\mathrm{O}_{\mathrm{w}}-\mathrm{H}\right) \\
\text { (stretching) }\end{array}$ & - & - & 3512 & 3435 \\
\hline $\begin{array}{l}\mathrm{v}(\mathrm{C}=\mathrm{O}) \\
(\text { stretching })\end{array}$ & 1701 & 1700 & 1694 & 1691 \\
\hline $\begin{array}{l}v(\mathrm{C}=\mathrm{N}) \\
(\text { stretching })\end{array}$ & 1597 & 1560 & 1385 & 1378 \\
\hline $\begin{array}{l}\mathrm{v}(\mathrm{C}-\mathrm{O}) \\
\text { (stretching) }\end{array}$ & 1256 & 1226 & 1215 & 1226 \\
\hline $\begin{array}{l}\mathrm{v}(\mathrm{M}-\mathrm{O}) \\
\text { (stretching) }\end{array}$ & 690 & 694 & 639 & 625 \\
\hline $\begin{array}{l}\mathrm{v}(\mathrm{M}-\mathrm{N}) \\
\text { (stretching) }\end{array}$ & 591 & 594 & 577 & 567 \\
\hline
\end{tabular}
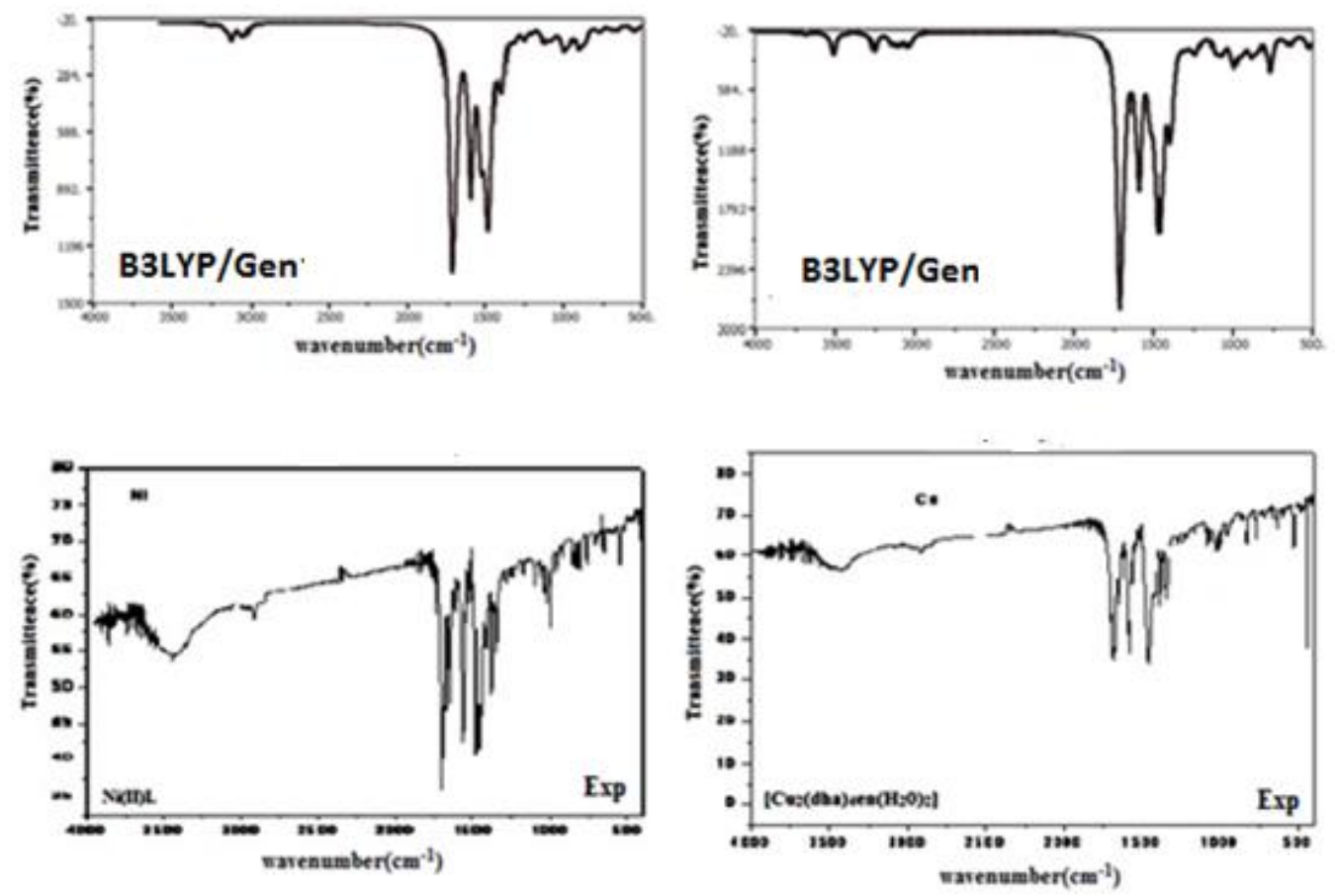

Fig. 7. Simulated versus experimental infrared spectra of [NiL]and $\left[\mathrm{Cu}_{2} \mathbf{L}_{2} \mathrm{H}_{2} \mathrm{O}\right], \mathrm{H}_{2} \mathrm{O}$. 


\subsection{Uv-vis absorption}

Absorption wavelengths in gas phase have been simulated at TDDFT/B3LYP level. Main electronic transitions can be found in Table 5, while the excited states and charge transfer character of electronic transitions are characterized by plotting the Natural Transition Orbitals for main states in Figure 8.

Table 5. Experimental $\lambda_{\exp }(\mathrm{nm})$ and calculated $\lambda_{\mathrm{Th}}(\mathrm{nm})$ wavelengths and $f$ oscillator strength for $[\mathrm{NiL}]$ and $\left[\mathrm{Cu}_{2} \mathbf{L}_{2} \mathbf{H}_{2} \mathbf{O}\right], \mathbf{H}_{2} \mathbf{O}$.

\begin{tabular}{|l|c|c|c|c|c|c|c|c|}
\hline \multirow{4}{*}{} & \multicolumn{4}{|c|}{$[$ NiL] } & \multicolumn{5}{c|}{$\left[\mathrm{Cu}_{2} \mathbf{L}_{2} \mathbf{H}_{2} \mathbf{O}\right], \mathbf{H}_{2} \mathbf{O}$} \\
\cline { 2 - 9 } & \multicolumn{2}{|c|}{ B3LYP } & \multicolumn{2}{c|}{ B3LYP } \\
\cline { 2 - 9 } & $\lambda_{\mathrm{Th}}$ & $f$ & $\lambda \exp$ & $\begin{array}{c}\text { Major } \\
\text { contribution }\end{array}$ & $\lambda_{\mathrm{Th}}$ & $f$ & $\lambda_{\exp }$ & $\begin{array}{c}\text { Major } \\
\text { contribution }\end{array}$ \\
\hline Band I & 278 & 0.014 & 281 & $\mathrm{H}-3 \rightarrow \mathrm{L}$ & 260 & 0.0015 & 260 & $\mathrm{H}-1 \rightarrow \mathrm{L}+5$ \\
\hline Band II & 310 & 0.001 & 310 & $\mathrm{H}-1 \rightarrow \mathrm{L}+2$ & 312 & 0.033 & 312 & $\mathrm{H}-3 \rightarrow \mathrm{L}+2$ \\
\hline Band III & 350 & 0.046 & 370 & $\mathrm{H} \rightarrow \mathrm{L}$ & 374 & 0.0012 & 374 & $\mathrm{H} \rightarrow \mathrm{L}+4$ \\
\hline Band IV & - & - & - & - & 562 & 0.0003 & 568 & $\mathrm{H} \rightarrow \mathrm{L}+1$ \\
\hline
\end{tabular}

For the complex [NiL], three absorption features have been calculated in the visible region, in good agreement with the well resolved experimental data. The NTO analysis shows that this transition is an absorption band at the $350 \mathrm{~nm}$ that originates mainly in the HOMO $\rightarrow$ LUMO electronic transition, a second band calculated at $310 \mathrm{~nm}$ with a main contribution from HOMO$1 \rightarrow$ LUMO +2 transition which is primarily $\pi \rightarrow \mathrm{d}$, a third transition is calculated at $278 \mathrm{~nm}$ due to the transfer charge from $n \rightarrow \pi$ and mainly originates from the HOMO-3 $\rightarrow$ LUMO. For the $\left[\mathrm{Cu}_{2} \mathrm{~L}_{2} \mathrm{H}_{2} \mathrm{O}\right], \mathrm{H}_{2} \mathrm{O}$ the lowest energy absorption is calculated at $562 \mathrm{~nm}$ and originates from the $\mathrm{HOMO} \rightarrow \mathrm{LUMO}+1$ transition associated to a charge transfer (CT) from $\mathrm{d}_{\mathrm{Cu}}$ orbitals to ligand and a $\mathrm{Cu} 2$ transfer MLCT, while the second transition calculated at $374 \mathrm{~nm}$ is attributed to $\mathrm{d}_{\mathrm{Cu} 1}$ to $\pi$ ligand charge transfer. The absorption band at $312 \mathrm{~nm}$ mainly involved the HOMO-3 $\rightarrow$ LUMO+2 transition it can be characterized by $n-\pi^{*}$ as shown in Figure 8 . Finally, the absorption at $260 \mathrm{~nm}$ presents an obvious $\pi \rightarrow \mathrm{d}$ character and mainly originates from HOMO- $1 \rightarrow \mathrm{LUMO}+5$. 


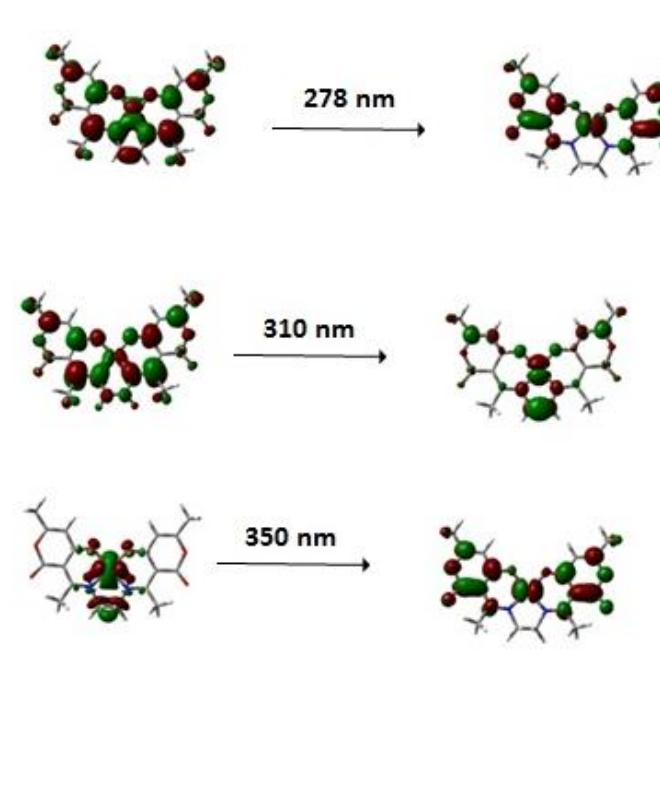

(a)

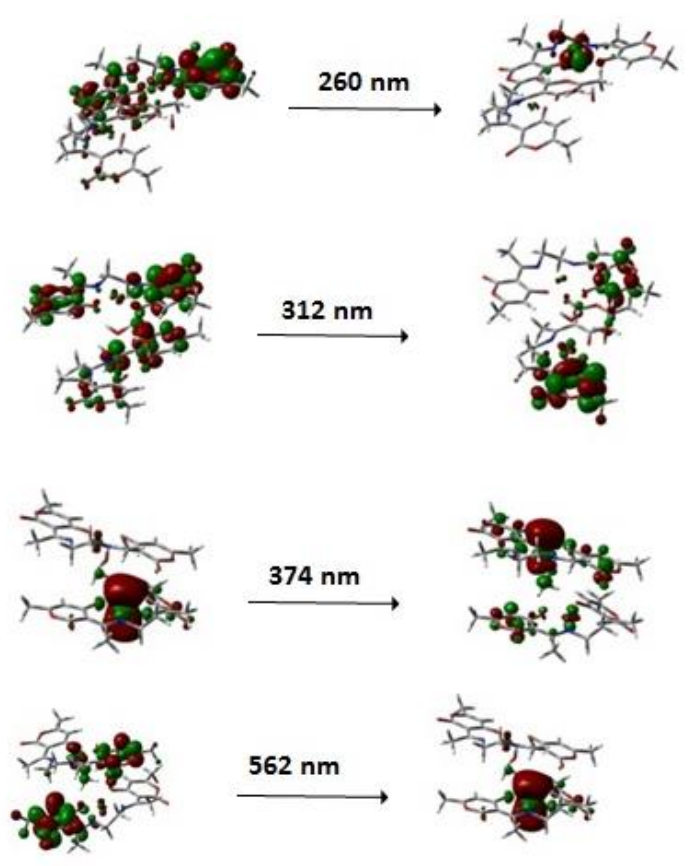

(b)

Fig. 8. Contour plots of the natural transition orbitals (NTOs) for both [NiL] (a) and $\left[\mathrm{Cu}_{2} \mathbf{L}_{2} \mathbf{H}_{2} \mathbf{O}\right]$, $\mathrm{H}_{2} \mathrm{O}$ (b).

\section{Conclusion}

In this paper, we have described the $[\mathrm{NiL}]$ and $\left[\mathrm{Cu}_{2} \mathrm{~L}_{2} \mathrm{H}_{2} \mathrm{O}\right], \mathrm{H}_{2} \mathrm{O}$ complexes. The metal center has square-planar coordination geometry for the complex of Ni metal and square pyramidal coordination geometry for the complex of $\mathrm{Cu}$ metal. The redox behavior was investigated by cyclic voltammetry. The metal complexes show both anodic and cathodic peaks which are due to redox reaction of the $\mathrm{Ni}^{\mathrm{II}} / \mathrm{Ni}^{\mathrm{I}}, \mathrm{Cu}^{\mathrm{II}} / \mathrm{Cu}^{\mathrm{I}}$ and $\mathrm{Cu}^{0} / \mathrm{Cu}^{\mathrm{II}}$ at the electrode surface for $\mathrm{NiL}$ and $\left[\mathrm{Cu}_{2} \mathrm{~L}_{2} \mathrm{H}_{2} \mathrm{O}\right], \mathrm{H}_{2} \mathrm{O}$ respectively. The theoretical study for both complexes on structural parameters, IR spectra, and UV-vis absorption gives values in excellent agreement with the experimental data.

\section{Acknowledgement}

We are grateful to MESRS and DGRSDT (Algeria) for financial support. We gratefully acknowledge support from the PSMN (Pôle Scientifique de Modélisation Numérique) computing center at Lyon, France. 


\section{References}

[1] I. Sylvestre, J. Wolowska, E.J.L. McInnes, C.A. Kilner, M. A. Halcrow.Inorg. Chem. Acta, 358(2005) 1337-1341.

[2]M. Thirumavalavan, P. Akilan, P. Amudha, M. Kandaswamy, Polyhedron, 23 (2004) 519-527.

[3] N.Mondal, S. Mitra, V. Gramlich, S.O. Ghodsi, KM.A . Malik, Polyhedron,20 (2001) 135-141.

[4] M.Amirnasr, K.J .Schenk, S. Meghdadi, M.Morshedi.Polyhedron. 25 (2006) 671-677.

[5] A.Bouchama, A. Bendaâs, C. Chiter, A. Beghidja, A. Djedouani, Acta Cryst. E 63 (2006) m2397.

[6] A. Djedouani, A. Bendaâs, S. Bouacida, A. Beghidja, T. Douadi, Acta Cryst. E 62 (2006) m133m135.

[7] M. Cindric, V. Vrdoljak, T. K. Novak, M. Curic, A. Brbot-Saranovic, B. Kamenar, J. Mol. Struc. 701 (2004) 111-118.

[8] M.Z. Chalaca, J.D. Figueroa-Villar, J.A. Ellena, E.E. Castellano, Inorg. Chim. Acta 328 (2002) 45-52.

[9] S.M. Jadhav , V.A. Shelke, S.G. Shankarwar, A.S. Munde, T.K. Chondhekar,J. Saudi, Chem. Soc.18 (2014) 27-34.

[10] S.A Munde, N.A Jagdale, M.S. Jadhav, K.T. Chondhekar, J. Serb. Chem. Soc. 75 (2010) 349-359.

[11] R.I. Kureshy, N.H. Khan, S.H.R. Abdi, P. Iyer, S.T. Patel, Polyhedron 18 (1999) 17731777.

[12] R.I. Kureshy, N.H. Khan, S.H.R. Abdi, P. Iyer, J. Mol. Catal. 124 (1997) 91-97.

[13] P.V. Rao, A.V. Narasaiah, Indian J. Chem. A 42 (2003) 1896-1899.

[14] D.T. Puerta, S.M. Cohen, Inorg. Chem. 42 (2003) 3423-3430.

[15] G. Battaini, E. Monzani, L. Casella, L. Santagostini, R. Pagliarin, J. Biol. Inorg. Chem. 5 (2000) 262-268.

[16] S. Thaisrivongs, D.L. Romero, R.A. Tommasi, M.N. Janakiraman, J.W. Strohbach, S.R. Turner, C. Biles, R.R. Morge, P.D. Johnson, P.A. Aristoff, P.K. Tomich, J.C. Lynn, M.M. Horng, K.T. Chong, R.R. WJ .Howe, BC .Finzel, KD. Watenpaugh, J. Med. Chem. 32 (1996) 4630-4642.

[17] T. I. Kashar, A. H. El-Sehli, J. Chem. Pharm. Res.5 (2013) 474-483.

[18] S. Thaisrivongs, D.L. Romero, R.A. Tommasi, M.N. Janakirman, J.W. Strohbach, S.R. Turner, C. Biles, R.R. Morge, P.D. Johnson, P.A. Aristoff, P.K. Tomich, J.C. Lymn, M.M. Horng, K.T. Chong, R.R. Hinshaw, W.J. Howe, B.C. Finzel and K.D. Watenpaugh, J. Med. Chem. 39 (1996) 4630-4642.

[19] P.A. Wolf, W.M. Westveer, Arch. Biochem. 28 (1950) 201-206. 
[20] S.G. Shirodkar, P.S. Mane, T.K. Chondhekar, Indian, J.Chem. 40 (2001) 1114-1117.

[21] V.A. Shelke, S.M.Jadhav, V.R. Patharkar, S.G. Shankarwar,A.S. Munde, T.K.Chondhekar ,J. Saudi. Chem. Soc. 5(2012) 501-507.

[22] “M86-E01078 APEX2 User Manual”, Bruker AXS Inc., Madison, USA, 2006.

[23] G.M. Sheldrick, SHELXS-97 program for crystal structure determination, Acta Crystallogr. A46 (1990) 467-473.

[24] G. Sheldrick, SHELXL-97, Universität Göttingen, Göttingen, Germany, 1999.

[25] M.J. Frisch, G.W. Trucks, H.B. Schlegel, G.E. Scuseria, M.A.nRobb, J.R. Cheeseman, G. Scalmani, V. Barone, B. Mennucci,G.A. Petersson, H. Nakatsuji, M. Caricato, X. Li, H.P. Hratchian, A.F. Izmaylov, J. Bloino, G. Zheng, J.L.Sonnenberg, M. Hada, M. Ehara, K. Toyota, R. Fukuda, J.Hasegawa, M. Ishida, T. Nakajima, Y. Honda, O. Kitao, H.Nakai, T. Vreven, J.A. Montgomery, Jr., J.E. Peralta, F.Ogliaro, M. Bearpark, J.J. Heyd, E. Brothers, K.N. Kudin,V.N. Staroverov, R. Kobayashi, J. Normand, K. Raghavachari,A. Rendell, J.C. Burant, S.S. Iyengar, J. Tomasi, M. Cossi, N.Rega, J.M. Millam, M. Klene, J.E. Knox, J.B. Cross, V.Bakken, C. Adamo, J. Jaramillo, R. Gomperts, R.E. Stratmann,O. Yazyev, A.J. Austin, R. Cammi, C. Pomelli, J.W. Ochterski,R.L. Martin, K. Morokuma, V.G. Zakrzewski, G.A. Voth,P. Salvador, J.J. Dannenberg, S. Dapprich, A.D. Daniels,O. Farkas, J.B. Foresman, J.V. Ortiz, J. Cioslowski, D.J. Fox, Gaussian Inc, Wallingford, CT, (2009)

[26] W. Kohn, L.J. Sham, Phys. Rev. 140 (1965) A1133-A1138.

[27] A.D. Becke, J. Chem. Phys. 98 (1993) 5648-5652.

[28] C. Lee, W. Yang, R.G. Parr, Phys. Rev. B37 (1998) 785-789.

[29] T .Sau-fun, A .Kok-Peng, Transition Met. 13(1988) 64-68.

[30] N. Batra, J. Devi, J. Chem. Pharm. Res. 2 (2015) 183-189.

[31] N. SK. Agrawal, DR.Tuflani, R. Gupta, SK. Hajela, Inorg. Chim. Acta 129 (1987) $257-$ 259.

[32] O.Carugo, C.B.Castellani, M.Rizzi, Polyhedron, 9 (1990) 2061-2069.

[33]Tahani I. Kashar and Amal H. El-Sehli. J. Chem. Pharm. Res., 2013, 5(11):474-483

[34] S.M. Jadhav, V.A. Shelke, S.G. Shankarwar, A.S. Munde, T.K. Chondhekar, J. Saudi, Chem. Soc. 18 (2014) 27-34.

[35] D.M. Fouad, A. Bayoumi, M. A. El-Gahami, S. A. Ibrahim, A. M. Hammam, Natural Science 2 (2010) 817-827.

[36] A. Golco, M .Tumer, H. Demirelli, R.A. Wheatly,Inorg. Chim. Acta 358 (2005) 1785-1797.

[37] M .Tumer, Synth. React. Inorg. Met. Chem. 30 (2000) 1139-1158. 
[38] J. Losada, I.D. Peso, L. Beyer, Synthesis, electrochemical properties and electro-oxidative polymerization of copper(II) and nickel(II) complexes with N-benzoylthiourea ligands containing pyrrole groups, Transit. Met. Chem. 25, 112-117 (2000).

[39]O. Diouf, Diariatou Gningue Sall, Mohamed Lamine Gaye, Abdou Salam SallC. R. Chim, 10 (2007) 473- 481.

[40] S.M. Emam, A.S. El-Tabl, H.M. Ahmed, E.A. Emad. j.arabjc

http://dx.doi.org/10.1016/j.arabjc.2014.05.019

[41] L.M. Shkolnikova, E.M. Yumal, E.A. Shugam, V. A. Voblikova, Zh. Strukt. Khim.11 (1970) 886-890.

[42] L. Ting-Fong, T. Sau-fun, A .Kok-Peng, C.W.M. Thomas, Transition Met. Chem.10 (1985) 375-379.

[43] D. Hall, A.J. McKinnon, T.N. Waters, J. Chem. Soc. (1965) 425.

[44] P.D.W. Boyd, A.D. Toy, T.D. Smith, J.R. Pilbrow, J. Chem. Soc. (1973) 1549-1563.

[45] W.B. Tolman, Acc. Chem. Res. 30 (1997) 227-237.

[46] A.Neves, L.M. Rossi, A.J. Bortoluzzi, B. Szpoganicz, C.Wiezbicki, E. Schwingel, W.Haase, S. Ostrovsky, Inorg. Chem. 41 (2002) 1788-1794.

[47] A. Neves, L.M. Rossi, I. Vencato, V. Drago,W. Haase, R.Werner, Inorg. Chim. Acta 281(1998) 111-115.

[48] R.A. Peralta, A.Neves, A.J. Bortoluzzi, A. dos Anjos, F.R. Xavier, B. Szpoganicz, H. Terenzi, M.C.B. de Oliveira, E. Castellano, G.R. Friedermann, A.S.Mangrich,M.A. Novak, J. Inorg. Biochem. 100 (2006) 992-1004.

[49] P. Mukherjee, M.G.B. Drew, A. Ghosh, Eur. J. Inorg. Chem. (2008) 3372.

[50]B. Sarkar, S. Konar, C.J. Gomez-Garcia, A. Ghosh, Inorg. Chem. 47 (2008) 11611.

[51] P.J. Hay and W.R. Wadt, J. Chem. Phys. 82 (1985) 299.

[52] R. L. Martin, J. Chem. Phys. 118 (2003) 4775-4777

[53]L. E. Roy, G. Scalmani, R. Kobayashi, E. R. Batista, Dalton transactions (2009) 6719-6721. 